\title{
Effect of grain refinement on superplasticity in micrograined materials
}

\begin{abstract}
F. A. Mohamed
famohame@uci.edu

Department of Chemical Engineering and Materials Science University of California, Irvine, CA 92697-2575, U. S. A.

Under superplasticity conditions, micrograined materials (grain sizes in the range $1 \mu \mathrm{m}-10 \mu \mathrm{m}$ ) exhibit extensive neck-free elongations during tensile deformation at elevated temperatures ( $\mathrm{T}>0.5 T_{m}$, where $T_{m}$ is the melting point). The deformation mechanism responsible for such behavior is based on grain boundary sliding accommodated by the generation and movement of lattice dislocations in the grains blocking sliding. Such a mechanism is characterized by a stress exponent of 2 , an activation energy that is close to that for boundary diffusion, and a grain size sensitivity of 2 . When the grain size of the material is refined to the ultrafine-grained range $(300 \mathrm{~nm}-900 \mathrm{~nm})$, there is no change either in the characteristics of superplasticity or in the details of its deformation mechanism. By contrast, when the grain size of the material is refined to the nanoscale range (grain size $\leq 100 \mathrm{~nm}$ ), superplasticity is lost due to the emergence of a new deformation mechanism. This new deformation mechanism is also based on grain boundary sliding accommodated by lattice dislocations. It is characterized by a stress exponent that is high and variable, an activation energy that is close to the activation energy for boundary diffusion but decreases with increasing applied stress, and a grain size sensitivity of 3 .
\end{abstract}

Keywords: boundary sliding, deformation mechanisms, nanocrystalline materials, ultrafine grained materials

\section{Влияние измельчения зерен на сверхпластичность в мелкозернистых материалах}

В условиях сверхпластичности мелкозернистые материалы (размер зерен в интервале $1-10$ мкм) демонстрируют большие удлинения без шейки при деформации растяжением при высоких температурах $\left(T>0.5 T_{m}\right.$, где $T_{m}-$ температура плавления). Механизм деформации, ответственный за такое поведение, основан на зернограничном проскальзывании, аккомодируемом генерацией и движением решеточных дислокаций в зернах, блокирующих проскальзывание. Этот механизм характеризуется показателем напряжения 2, активационной энергией, которая близка к активационной энергии диффузии по границам, и чувствительностью к размеру зерен 2. Когда размер зерен материала измельчается до интервала, соответствующего ультрамелкозернистым материалам (300-900 нм), ни в характеристиках сверхпластичности, ни в деталях деформационных механизмов не происходит никаких изменений. Однако когда зерна измельчаются до наноразмерного уровня (размер зерен менее 100 нм), сверхпластичность теряется из-за появления нового деформационного механизма. Этот новый деформационный механизм также основан на зернограничном проскальзывании, аккомодируемом решеточными дислокациями. Он характеризуется показателем напряжения, который имеет высокое изменяющееся значение, активационную энергию, которая близка к активационной энергии диффузии по границам, но уменьшается с увеличением приложенного напряжения, и чувствительностью к размеру зерен 3.

Ключевые слова: граничное проскальзывание, деформационные механизмы, нанокристаллические материалы, ультрамелкозернистые материалы

\section{Introduction}

Detailed studies on creep in materials are of scientific and practical significance. From a scientific point of view, data obtained from such studies are critical to the characterization of creep in terms of deformation mechanisms. From a practical point of view, information inferred from such studies is beneficial to the design and safety of high-temperature applications. As a result, over the past several decades, the creep behavior of various groups of materials has been extensively investigated. These groups include metals, solid solution alloys, intermetallics, composites, ceramics, superplastic alloys, dispersion-strengthened alloys, ultrafine-grained (UFG) materials, and nanocrystalline (nc) materials. In establishing 
the creep behavior of these groups of materials, several relationships that define the basic deformation characteristics associated with a creep process were evaluated. Primary among these relations are the following:

a. The relationship between strain rate and stress, $\tau$, yields two parameters: the stress exponent, $n$, and the activation volume, $v$. The stress exponent, $n$, and the activation volume, $v$, are respectively, given by:

$$
n=(\partial \ln \dot{\gamma} / \partial \ln \tau)_{T, d}
$$

and

$$
v=k T \frac{\partial \ln \dot{\gamma}}{\partial \tau}
$$

where $\dot{\gamma}$ is the strain rate and $\mathrm{k}$ is Boltzmann's constant.

b. The relationship between strain rate and temperature, $T$, at constant $d$, and stress, $\tau$, provides the value of the activation energy for creep, $Q_{a}$, that is given by:

$$
Q=\partial \ln \dot{\gamma} / \partial(-1 / R T)
$$

where $R$ is the gas constant.

c. The relationship between strain rate, $\dot{\gamma}$, and grain size, $\mathrm{d}$, at constant temperature, $\mathrm{T}$, and stress, $\tau$, produces the value of the grain sensitivity, $s$, that is defined as:

$$
s=(\partial \ln \dot{\gamma} / \partial \ln d)_{T, \tau}
$$

The aforementioned relationships along with microstructural details have been applied to obtain guiding information that can be used in part to examine whether an existing deformation mechanism can explain the creep behavior of a material or a new mechanism should be developed to account for the behavior. In this paper, two examples are provided for the purpose of illustration. The first example demonstrates that the deformation mechanism developed for superplasticity in micrograined materials can explain the deformation behavior and substructural features in a superplastic UFG Al alloy. The second example indicates that information on the deformation of nc materials cannot be accounted for either by the deformation mechanism for superplasticity in micrograined materials or by other available deformation mechanisms; and that a new mechanism is required.

\section{Analysis and discussion}

\subsection{Superplasticity in micrograined materials}

Under the conditions of superplasticity, micrograined materials (grain sizes in the range $1 \mu \mathrm{m}-10 \mu \mathrm{m}$ ) exhibit extensive neck-free elongations during tensile deformation at elevated temperatures $\left(T>0.5 T_{m}\right.$, where $T_{m}$ is the melting point). These large elongations are usually greater than $350 \%$ and sometimes in excess of $2000 \%$. The two basic requirements for a material to display superplastic behavior are: (a) a fine and equiaxed grain size that does not undergo significant growth during high temperature deformation, and (b) high-angled grain boundaries that are mobile and able to resist tensile separation.

The superplastic behavior of a micrograined material where maximum ductility occurs over several orders of magnitude of strain rate and is characterized by a stress exponent, $\mathrm{n}$ (defined by Equation 1) of 1.5 to 2.5, an activation energy, Q (defined by Equation 3) that is close to that for boundary diffusion, and grain size sensitivity, s (defined by Equation 4) is about 2 [1-3].

In addition, the strong sensitivity of steady-state creep rates measured during superplastic flow to changes in grain size along with the temperature dependence of strain rate ( $Q$ is equal that for boundary diffusion) have indicated that boundaries play an important role, which is related to their ability to contribute to deformation through the process of boundary sliding. Over the past several decades, considerable efforts have been made to characterize the nature and significance of such a role in terms of deformation mechanisms. As a result of these efforts, several deformation mechanisms were developed or speculated [4-8]. The most successful mechanisms are based on grain boundary sliding (GBS) accommodated by dislocation motion [5-8]. These models are different in details and assumptions. Despite these differences, all models based on GBS accommodated by dislocations can be represented by the following expression:

$$
\dot{\gamma}=C \frac{D_{0} G b}{k T}\left(\frac{b}{d}\right)^{2}\left(\frac{\tau}{G}\right)^{2} \exp \left(\frac{-Q_{g b}}{R T}\right)
$$

where $\mathrm{C}$ is a dimensionless constant that can be evaluated from the details of each mechanism, Do is the frequency factor for diffusion, $G$ is the shear modulus, $b$ is the Burgers vector, $d$ is the grain size, $s=2$ is the grain size sensitivity, $n=2$ is the stress exponent, and $Q_{\mathrm{gb}}$ is the activation energy for boundary diffusion.

As mentioned above, the models of GBS accommodated by dislocation motion incorporate lattice dislocation activity [5-8] as a major component in the rate-controlling process of superplastic flow. Two detailed investigations in which the technique of transmission electron microscopy (TEM) wasused were carried out $[9,10]$ in an effort to examine whether lattice dislocations were active during superplastic flow. In these two investigations $[9,10]$, experiments were conducted on the superplastic Zn-22\%Al eutectoid containing nanometer-scale dispersion particles. These particles were introduced in the matrix of the alloy via powder metallurgy followed by cryomilling [11]. TEM examination of specimens deformed at a strain rate near the center of the superplastic region have revealed the following observations [9,10]: (a) the initial microstructure is nearly dislocation free, (a) after deformation, only some grains contain dislocations, which interact with dispersion particles, (c) the configurations of the lattice dislocations in the interiors of these grains are suggestive of viscous glide and single slip, and (d) most of the dislocations are parallel; they tend to be long and curved; and they appear to sweep across the grain interior one by one. Fig. 1 provides an example for the configurations of the lattice dislocations in the interiors of the grains of $\mathrm{Zn}-22 \% \mathrm{Al}$.

The above observations are consistent with the details 


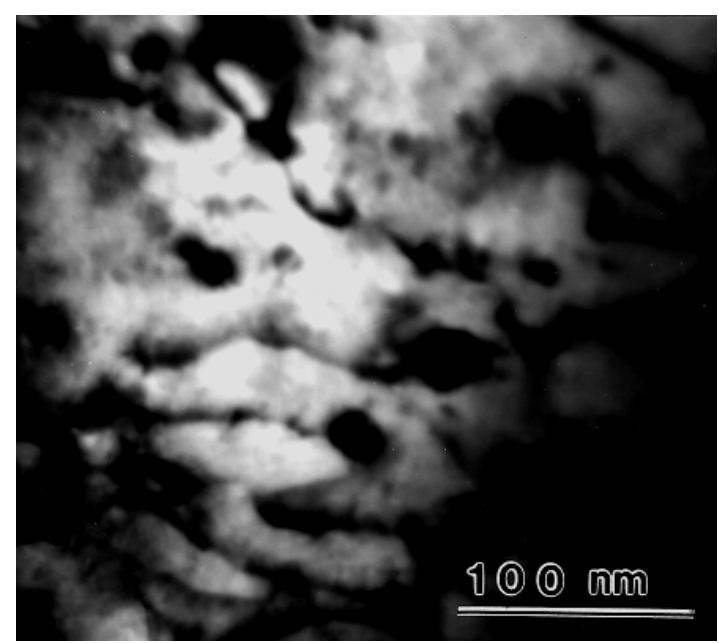

Fig. 1. Configuration of dislocations during superplastic flow in $\mathrm{Zn}-22 \% \mathrm{Al}[9,10]$.

of the model of Ball and Hutchison [5] in which a group of grains slide as a unit until blocked by an unfavorably oriented grain, and grain boundary sliding is accommodated by the generation and movement of lattice dislocations in the blocking grain.

\subsection{Superplasticity in ultrafine-grained materials}

While superplasticity in micrograined materials ( $d$ in the range $1 \mu \mathrm{m}-10 \mu \mathrm{m}$ ), is characterized by large elongations that are equal to or greater than $350 \%$, these large elongations are usually attained at strain rates in the range of $10^{-3}-10^{-2} \mathrm{~s}^{-1}$. Such a strain rate range is too slow to be useful for commercial forming of structural materials, which is normally performed at strain rates $>10^{-2} \mathrm{~s}^{-1}$. Recent efforts were devoted to addressing this problem. These efforts have led to the emergence of high-strain rate (HSR) superplasticity, which is very beneficial for commercial applications. The concept for HSR is based on the finding [12] that the ductility-strain rate curve of a micrograined superplastic alloy shifts to higher strain rates with decreasing the grain size. This finding has suggested an approach to induce highstrain rate (HSR) superplasticity via grain refinement. For the purpose of grain refinement, equal-channel angular pressing (ECAP) [13], high-pressure torsion (HPT) [14], friction stir (FS) [15] processing, and cryomilling followed by consolidation [11] have been be used. Several examples for HSR in ultrafine-grained alloys that were prepared by ECAP, HPT, and SF were extensively discussed elsewhere [16-18]. Accordingly, it seems appropriate to provide an example for HSR superplasticity in an Al alloy [19] that was processed via cryomilling [20].

The alloy selected for refinement was $5803 \mathrm{Al}$ (Al-94.7\%, $\mathrm{Mg}-4.86 \%$, and $\mathrm{Cr}-0.7 \%)$. The microstructure of $5083 \mathrm{Al}$ after cryomilling followed by consolidation and extrusion exhibited an average grain size of about $305 \mathrm{~nm}[19,20]$. After annealing for 30 minutes at $673 \mathrm{~K}$, an examination of the microstructure of the alloy revealed that the grain size was about $440 \mathrm{~nm}[19,20]$.

The deformation behavior and microstructural features in $5083 \mathrm{Al}$ provide an example not only for illustrating HSR in UFG grained materials but also for demonstrating the validity of the deformation mechanism for superplasticity in micrograined materials to the description of the mechanical characteristics and substructural features noted in the UFG $\mathrm{Al}$ alloy. Consideration of the mechanical characteristics of $5083 \mathrm{Al}$ led to two main findings [19]. First, the creep characteristics of $5083 \mathrm{Al}$ were consistent with those associated with HSR superplasticity. This consistency is demonstrated by the following observation: optimum elongations of about $400 \%$ were obtained at strain rates $>0.1 \mathrm{~s}^{-1}$. Second, the creep characteristics are similar to those reported for superplasticity in micrograined materials: (i) a true stress exponent that is about 2, and (ii) an activation energy that approximates to that for grain boundary diffusion. These two characteristics were also reported for several alloys processed by ECAP and HPT [16]. Equally important are the substructural features observed in the alloy [19] following deformation. These features are typical of those reported for micrograin superplasticity in $\mathrm{Zn}-22 \% \mathrm{Al}$ that contained dispersion particles (introduced via cryomilling) $[9,10]$. First, an equiaxed grain structure was present after extensive creep deformation. Second, there existed clear evidence of the occurrence of grain boundary sliding and its features such as offsets, voids, striated bands, and rotation of grains (Fig. 2). Third, dislocations were present in only few grains while most of the grains were found to have extremely low dislocations density; (b) most of the dislocations were parallel (Fig. 3) and tended to be long and curved. Finally,
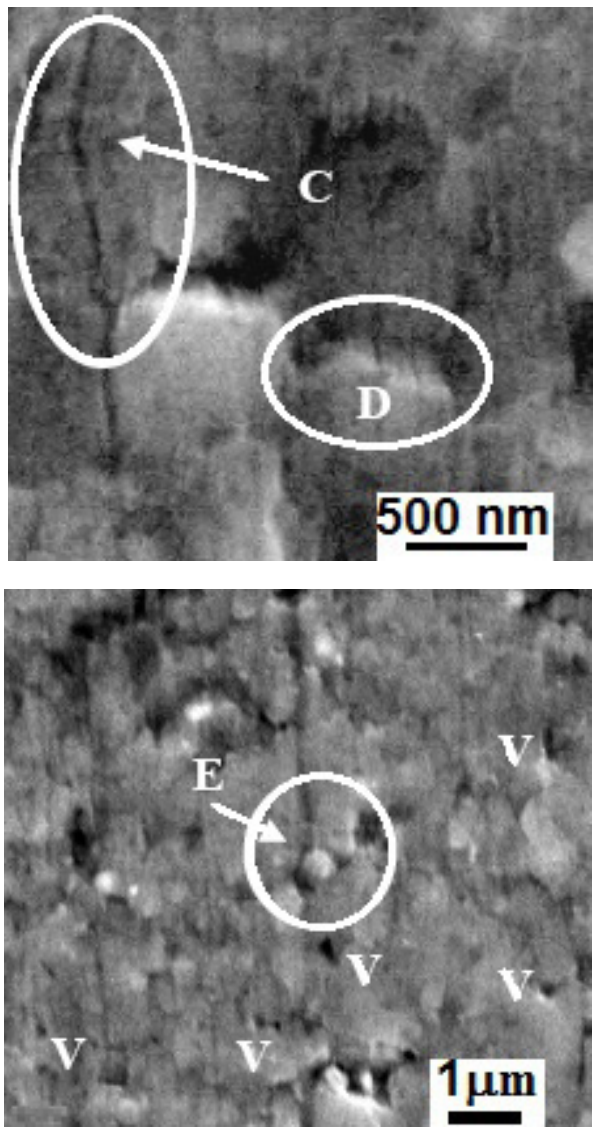

Fig. 2. Evidence for boundary sliding in UFG 5083Al: grain rotation (“C”), striated bands ("D"), formation of voids ("V"), emergence of new grains. 


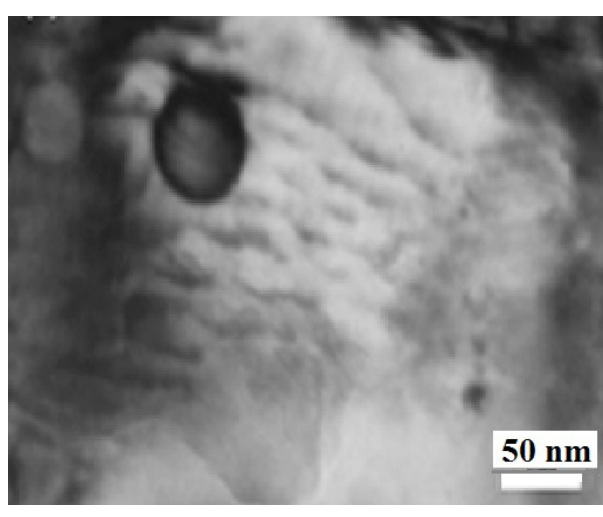

a

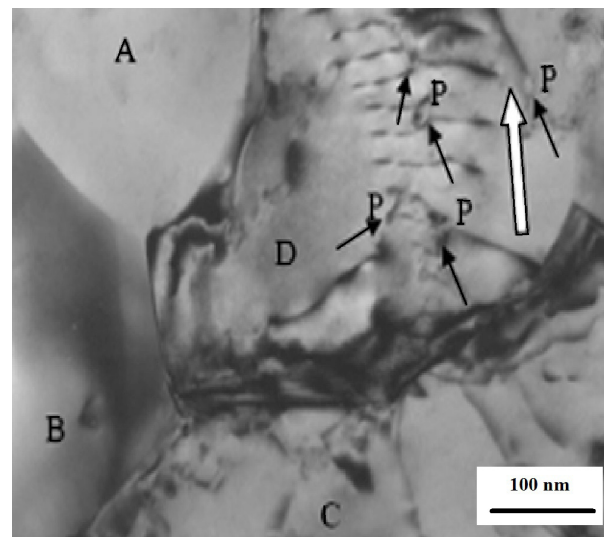

b

Fig. 3. Dislocation configurations in UFG $5083 \mathrm{Al}$ prepared via cryomilling [19].

many of the dislocations noted in the interiors of grains were attached to dispersion particles (Fig. 3). Nano-scale particles were naturally introduced in $5083 \mathrm{Al}$ during the process of gas atomization and cryomilling. These particles

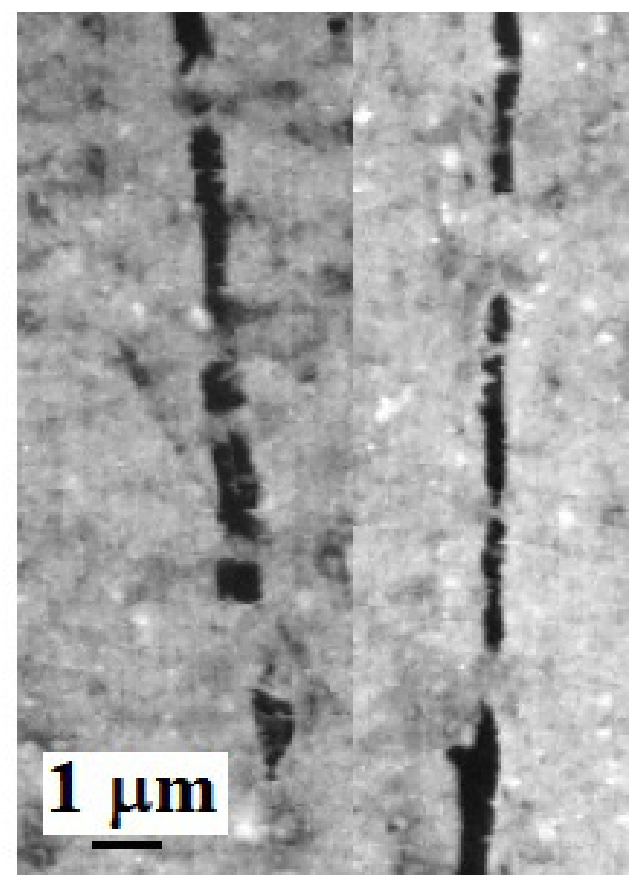

Fig. 4. The presence of cavity stringers in UFG $5083 \mathrm{Al}$ along the tensile axis (vertical) [19]. served as a marker to monitor dislocation activity during deformation. Finally, Cavity stringers were observed (Fig. 4), This substructural feature is associated with superplasticity in micrograined alloys such as $\mathrm{Zn} 22 \% \mathrm{Al}$.

The aforementioned similarities in creep behavior and its substructural features between UFG $5053 \mathrm{Al}$ alloy and that of $\mathrm{Zn}-22 \% \mathrm{Al}$ containing nanometer-scale dispersion particles indicates that the model of boundary sliding accommodated by lattice dislocation is applicable to the description of superplastic flow in the former material.

\subsection{Superplasticity in nanocrystalline materials}

Nanocrystalline (nc) materials are characterized by an average grain size that is $\leq 100 \mathrm{~nm}$. Because of this characteristic, grain boundaries, junction lines, and nodes have significant volume fractions - substructural features that can influence properties far more strongly than in conventional materials [21]. Accordingly, nc-materials offer novel properties that may be exploited for useful application, which require high strength and exceptional hardness. As a result of recent investigations on nc materials, extensive experimental data on the deformation behavior of these materials have become available. The data show that the creep behavior cannot be explained by Equation (5), which is applicable to the description of superplasticity in micrograined and ultrafine grained materials for the following reasons: (a) ductility is very limited (less than 12\%); (b) the stress exponent is high and variable; (c) the grain size sensitivity is 3 not 2, and (d) an activation energy that is close to the activation energy for boundary diffusion but decreases with increasing applied stress. Although several mechanisms [22-25] were mentioned or developed to account for the deformation behavior of nc materials, it has been shown that the predictions of the model of dislocation-accommodated boundary sliding (DABS) [26] are consistent with the above characteristics.

The basic concept used in developing the model of DABS $[25,26]$ is that plasticity in nc-materials is the result of boundary sliding accommodated by the generation and motion of dislocations under local stresses, which are higher than applied stresses due to the development of stress concentrations. The model, unlike that of Ball and Hutchison [5] for superplasticity in micrograined materials, does not involve a dislocation pile-up at the opposite boundary of the grain blocking sliding. By considering the details of sliding and dislocation climb along the boundary, the following ratecontrolling equation was derived [25]:

$$
\dot{\gamma}=9\left(\frac{b}{d}\right)^{2}\left(\frac{D_{0}}{b^{2}}\right) \exp \left(\frac{-Q_{g b}}{R T}\right)\left[\exp \left(\frac{v \tau}{k T}\right)-1\right]
$$

The data reported for $\mathrm{nc} \mathrm{Ni}$ and $\mathrm{nc} \mathrm{Cu}$ were plotted [27] in terms of the two normalized parameters: $\gamma(d / b)^{3}\left(b^{2} / D_{\mathrm{gb}}\right)$ and $\exp (v \tau / k T)-1$, as shown in Figure 5. Also included in the figure is a solid straight line that represents the prediction.

Correlation between the data reported for $\mathrm{nc} \mathrm{Ni}$ and $\mathrm{nc}$ $\mathrm{Cu}$ and the prediction of the model based on grain boundary sliding accommodated by lattice dislocations of Equation (6). It is clear that the datum points cluster about the solid 


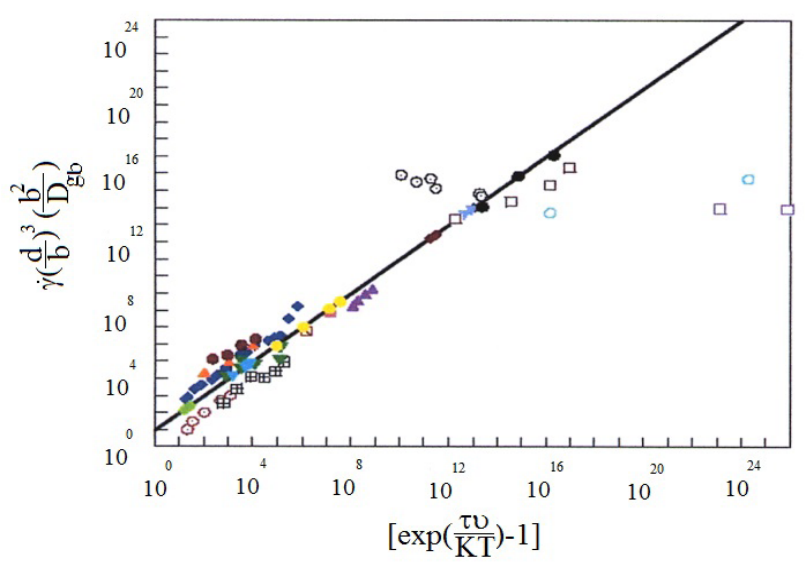

Fig. 5. Correlation between the data reported for $\mathrm{nc} \mathrm{Ni}$ and $\mathrm{nc} \mathrm{Cu}$ and the prediction of the model based on grain boundary sliding accommodated by lattice dislocations.

line, demonstrating the presence of good correspondence between the rate-equation representing this deformation process and the experimental data for $\mathrm{nc} \mathrm{Ni}$ and $\mathrm{nc} \mathrm{Cu}$, which were obtained under different conditions of temperature, grain size, and strain rates [27].

As indicated above, when the grain size decreases from the micrograined range $(1 \mu \mathrm{m}-10 \mu \mathrm{m})$ to the UFG range $(300 \mathrm{~nm}-800 \mathrm{~nm})$, the superplastic region associated with maximum ductility is transposed to high strain rates, i.e., high-strain rate superplasticity is achieved. By contrast, as available data show, when the grain size decreases from the micrograin range to the nanograin range $(\mathrm{d} \leq 100 \mathrm{~nm})$, ductility becomes very limited; ductility does not exceed $10 \%$. From a mechanical point of view, such a difference can be explained by comparing Equation (5), which represents superplastic behavior, with Equation (6), which represents the mechanism of DABS. Such a comparison shows while the stress exponent for creep in micrograined superplastic alloys, $\mathrm{n}$, is equal to 2, the stress exponent for deformation in nc materials as estimated from Equation (6), exhibits high and variable values; for the applicable range of stresses and strain rates, $\mathrm{n}=10-50$. Accordingly, it is expected that ductility in nc-materials would be much lower than those characterizing superplastic flow in micrograined and ultrafine grained alloys, since ductility depends on $1 / \mathrm{n}$ as shown by the following equation [28]:

$$
e_{f}=[\exp (C /(n-1))-1]
$$

where $C=(n-(1 / n)) \ln (400 / n)$. As shown in reference [25], combining Equation (6) and (7) leads to predicting that ductility not only is low but also is in the range $2-8 \%$ From a microstructural point of view, the low ductility of nc materials can also be explained in terms of the details of the concept of DABS [27]. According to the concept, dislocations are generated under the local stresses and move in the blocking grains to boundaries where they are annihilated. This scheme results in the absence of dislocation accumulation and interactions, i.e., nanograins are not able to sustain arrays of dislocations. This leads to loss of work hardening, which in turn results in low ductility.
Ductility in nc materials can be improved by introducing substructural features that impede the motion of the generated dislocations to boundaries and enhance dislocation interactions. These features include a bimodal grain size distribution, deformation twins, annealing twins, or a combination of a bimodal grain size distribution and twins [29].

\section{Summary}

(1) Three severe plastic deformation techniques, ECAP, HPT and FR have been extensively utilized in producing ultrafine-grained materials that exhibit high-strain rate superplastic behavior. In this paper, an example for producing an UFG Al alloy via cryomilling followed by consolidation is given.

(2) The deformation mechanism for high-strain rate superplasticity in ultrafine-grained alloys is identical with that controlling superplasticity in micrograined materials. This conclusion is based on the evidence that creep characteristics, mechanical and substructural, are similar in both types of materials.

(2) Observation of superplasticity in nanocrystalline materials has so far been unsuccessful. This can be explained using the predictions of the mechanism of DABS: (a) the stress exponent, $\mathrm{n}$, for creep in nanocrystalline materials is in the range $10-50$; by contrast, $\mathrm{n}$ for superplastic flow in micrograined and ultrafine-grained alloys is equal to 2 , and (b) the absence of dislocation accumulation and interactions, i.e., nanograins are not able to sustain arrays of dislocations. This leads to loss of work hardening, which in turn results in low ductility.

Acknowledgements. This work was supported by National Science foundation under several grants including Grant No DMR-0702978, Grant No DMR-0304629, and Grant number No DMR-9810422. The author wishes to acknowledge his former graduate students, Dr.P. Chaudhury, Prof. K. T. Park, Dr.K. Duong, Dr.A. Yousefiani, Dr. Yuwei Xun, Dr.M. Chauhan, and Dr.I. Roy, who significantly contribute to this work.

\section{References}

1. F. A. Mohamed, T.G. Langdon, Acta. Metall. 23, 117 (1975).

2. F. A. Mohamed, S. A. Shei, T.G. Langdon, Acta. Metall. 23, 117 (1975).

3. F. A. Mohamed, T.G. Langdon, Philos. Mag. 32, 697 (1975).

4. M. F. Ashby, R. A. Verrall. Acta Met. 21, 149 (1973).

5. A. Ball, M. M. Hutchison, Metal Sci. J. 3, 1 (1969).

6. A. K. Mukherjee, Mater. Sci. Eng. 8, 83 (1971).

7. R. C. Gifkins, Met. Trans. A, 7A, 1225 (1976).

8. J.H. Gittus, Trans. ASME, H, J.Eng. Mater. Technol. 99, 244 (1977).

9. Y. Xun, F. A. Mohamed, Phil. Mag. 83, 2247 (2003).

10. Y. Xun, F. A. Mohamed, Acta Mater, 52, 2247 (2004). 
11. D. B. Witkin, E. J. Lavernia, Prog. Mater. Sci. 51, 1 (2006).

12. F. A. Mohamed, M. M. I. Ahmed, T.G. Langdon, Metall. Mater. Trans. 8A, 933 (1977).

13. R.Z. Valiev, T.G. Langdon, Prog Mater Scie. 51, 881 (2006)

14. A.P. Zhilyaev, T.G. Langdon, Prog Mater Scie. 53, 893 (2008).

15. R. S. Mishra, Z. Y. Ma, Mater Sci Eng, R50, 1, (2005).

16. M. Kawasaki, N. Balasubramanian, T.G. Langdon, Mater Sci. Eng. A, 528, 6624 (2011).

17. M. Kawasaki, T. G. Langdon, J. Mater Sci. 49, 6496 (2014).

18. A. Mohan, W. Yuan, R. S. Mishra, Mater Sci. Eng. A, 562, 69 (2013).

19. M. Chauhan, I. Roy, F. A. Mohamed, Metall. Mater. Trans. A, 37A, 2715 (2006).

20. I. Roy, M. Chauhan, E. J. Lavernia, F. A. Mohamed, Metall
Mater Trans. 37A, 721 (2006).

21. H. Gleiter, Acta Mater. 48, 1, 1 (2000).

22. R. A. Masumura, P. M. Hazzledine, C.S. Pande, Acta Mater. 46, 13, 4527 (1998).

23. H. Conrad, J. Narayan, Scripta Mater. 42, 11, 1025 (2000)

24. G. J. Fan, H. Choo, P. K. Liaw, E. J. Lavernia, Met. Mater. Trans. A, 36A, 102641 (2005).

25. F. A. Mohamed, M. Chauhan, Met. Mater. Trans. A, 37A, 12, 3555 (2006).

26. F. A. Mohamed, H. Yang, Met. Mater. Trans. A, 41A, 823 (2010).

27. F. A. Mohamed, Met. Mater. Trans. A, 38A, 340 (2007).

28. F. A. Mohamed, Scripta Mater. 13, 87, (1979).

29. H. Yang, F. A. Mohamed, Mater. Sci. Forum, 411, 633 (2010) 